\title{
Minibus taxi drivers' sexual beliefs and practices associated with HIV infection and AIDS in KwaZulu- Natal, South Africa
}

\begin{tabular}{|c|c|}
\hline Authors: & \\
\hline $\begin{array}{l}\text { Busisiwe Ncan } \\
\text { Gugu Mchunu }\end{array}$ & \\
\hline Joanne Naido & \\
\hline Sisana Majeke & \\
\hline Padmini Pillay & \\
\hline Thandazile My & eza ${ }^{1}$ \\
\hline Thandiwe Nde & bele ${ }^{1}$ \\
\hline $\begin{array}{l}\text { Affiliations: } \\
{ }^{1} \text { Department } \\
\text { University of } \\
\text { South Africa }\end{array}$ & $\begin{array}{l}\text { f Nursing, } \\
\text { waZulu-Natal, }\end{array}$ \\
\hline $\begin{array}{l}{ }^{2} \text { Human Scien } \\
\text { Council, South }\end{array}$ & $\begin{array}{l}\text { ces Research } \\
\text { Africa }\end{array}$ \\
\hline $\begin{array}{l}{ }^{3} \text { Department } \\
\text { Durban Unive } \\
\text { Technology, Sc }\end{array}$ & $\begin{array}{l}\text { f Nursing, } \\
\text { rsity of } \\
\text { uth Africa }\end{array}$ \\
\hline $\begin{array}{l}\text { Corresponden } \\
\text { Busisiwe Ncan }\end{array}$ & $\begin{array}{l}\text { ice to: } \\
\text { na }\end{array}$ \\
\hline $\begin{array}{l}\text { Email: } \\
\text { ncamab@ukzr }\end{array}$ & ר.ac.za \\
\hline $\begin{array}{l}\text { Postal addres } \\
\text { Howard Colleg } \\
\text { Durban } 4021 \text {, }\end{array}$ & $\begin{array}{l}\text { Se Campus, } \\
\text { South Africa }\end{array}$ \\
\hline $\begin{array}{l}\text { Dates: } \\
\text { Received: } 12 \text { S } \\
\text { Accepted: } 10 \\
\text { Published: } 08\end{array}$ & $\begin{array}{l}\text { ept. } 2011 \\
\text { Aug. } 2012 \\
\text { Jan. } 2013\end{array}$ \\
\hline $\begin{array}{l}\text { How to cite th } \\
\text { Ncama, B., Mc } \\
\text { Naidoo, J., Ma } \\
\text { Pillay, P., Myez } \\
2013, \text { 'Minibu } \\
\text { sexual beliefs } \\
\text { associated wit } \\
\text { and AIDS in Kv } \\
\text { South Africa', } \\
\text { 36(1), Art. \#59 } \\
\text { http://dx.doi.c } \\
\text { curationis.v36 }\end{array}$ & $\begin{array}{l}\text { is article: } \\
\text { hunu, G., } \\
\text { jeke, S., } \\
\text { a, T. et al., } \\
\text { s taxi drivers' } \\
\text { and practices } \\
\text { h HIV infection } \\
\text { vaZulu-Natal, } \\
\text { Curationis } \\
, 6 \text { pages. } \\
\text { rg/10.4102/ } \\
1.59\end{array}$ \\
\hline $\begin{array}{l}\text { Copyright: } \\
\text { (C) 2013. The A } \\
\text { Licensee: AOS } \\
\text { OpenJournals } \\
\text { is licensed unc } \\
\text { Creative Comr } \\
\text { Attribution Lic }\end{array}$ & $\begin{array}{l}\text { IS } \\
\text { IS } \\
\text { This work } \\
\text { der the } \\
\text { nons } \\
\text { ense. }\end{array}$ \\
\hline Read online: & \\
\hline 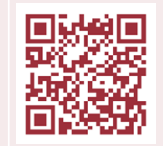 & $\begin{array}{l}\text { Scan this QR } \\
\text { code with your } \\
\text { smart phone or } \\
\text { mobile device } \\
\text { to read online. }\end{array}$ \\
\hline
\end{tabular}

Authors:

Thandazile Myeza

University of KwaZulu-Nat

South Africa

${ }^{2}$ Human Sciences Research

${ }^{3}$ Department of Nursing,

Durban University of

Correspondence to:

Email:

Postal address:

Howard College Campus,

Received: 12 Sept. 2011

Accepted: 10 Aug. 2012

How to cite this article: Ncama, B., Mchunu, G.

Naidoo, J., Majeke, S. associated with HIV infection and AIDS in KwaZulu-Natal, South Africa', Curationis 36(1), Art. \#59, 6 pages. http://dx.doi.org/10.4102/ curationis.v36i1.59

\section{Copyright:}

(C) 2013. The Authors.

is licensed under the

Creative Commons

Attribution License.

Read online:
Risky sexual behaviours in South Africa are a major contributing factor to the spread of HIV infection and AIDS. HIV infection amongst minibus taxi drivers is a concern, because these people belong to an occupational group that exhibits risky behaviours due to the demands of their work. Given the high vulnerability of minibus taxi drivers, exploring the sexual beliefs and health-related sexual practices of this group will assist in planning targeted interventions.

The objectives of this study were to assess the level of knowledge, beliefs and practices regarding HIV infection and AIDS amongst minibus taxi drivers. An exploratory descriptive study was conducted using a pre-tested questionnaire to explore and describe sexual beliefs and practices associated with HIV infection and AIDS in a convenience sample of 175 minibus taxi drivers. Permission to undertake the study was obtained from the KwaZulu-Natal Taxi Alliance and individuals who participated in the study. Data analysis were analysed using the Statistical Package for Social Sciences 13.0. The study revealed that minibus taxi drivers are one of the high- risk groups in the spread of HIV infection and AIDS; they lack necessary education and need attention in relation to control and prevention of the spread of HIV and AIDS. Multiple sexual partners are relatively common amongst the minibus taxi drivers. Violence against women and even forceful sexual intercourse in the belief that women should tolerate it to keep the family together was reported. There is a need for intervention programmes with a focus on minibus taxi drivers and similar high-risk groups. Prevention activities should incorporate the distribution of condoms amongst this group and HIV prevention educational programmes, as well as creating mechanisms for accessing circumcision by the minibus taxi drivers.

\section{Introduction}

According to a population survey, HIV prevalence in the total population of South Africa has stabilised at a level of around $11 \%$ in the population that is over two years of age. KwaZuluNatal is the worst affected province, with antenatal prevalence of HIV infection at $38.7 \%$ (Shisana et al. 2009).

Concurrent sexual partnerships, where sexual relationships overlap in time, are noted to be a major factor contributing to the rapid growth of HIV infections, and qualitative research illustrates that such partnerships are normative in South Africa (Parker et al. 2009). South Africa was estimated to have 5.7 million persons living with HIV infection by 2005 (UNAIDS 2010). Whilst risk of HIV infection increases as a product of having many sexual partners, it is particularly risky to have concurrent sexual partners as this creates multiple pathways for HIV transmission to occur. Age of sexual debut has emerged as an important variable in the prevention of HIV infection, both in South Africa and globally (UNAIDS 2008). Risky sexual behaviours in South Africa have been implicated as a major contributing factor in the spread of HIV infection.

HIV infection and AIDS are a major threat to all sectors and especially the economic sectors, and the workforce is largely affected. It is estimated that the prevalence of HIV infection amongst workers is as follows: $13 \%$ of the highly skilled workers, $23 \%$ of the skilled and $33 \%$ of the unskilled workers are infected with HIV, and that unskilled workers are more likely than skilled and highly skilled workers to be infected with HIV (Evian et al. 2004; Vass 2005).

Despite extensive efforts by various governments and non-governmental organisations in promoting safe sex in South Africa, condom use amongst young adults (both males and females) is relatively low, with many still engaging in unprotected sexual activities, putting them at greatest risk of acquiring HIV infection (Bankole et al. 2007). The prevention and control of HIV infection and AIDS remains a challenge to healthcare policy makers and healthcare providers worldwide 
(Guiella \& Madise 2007). Despite the threat posed by HIV infection, many subgroups in the population continue to engage in risky sexual behaviour, possibly due to ignorance, disbelief or sheer recklessness (Figueroa 2008).

\section{Problem statement}

HIV-preventive interventions have been criticised for being a 'one size fits all' approach and not specific to the needs of target groups. The impact of HIV infection and AIDS on industry and the business sector at large cannot be underestimated. Semi-skilled and unskilled workers contribute significantly to driving the economy (Evian et al. 2004). The minibus taxi industry falls under the unskilled sector and is the backbone of the transport industry, with the minibus industry accounting for $60 \%$ of public commuting services (Orisatoki \& Oguntibeju 2010). The industry comprises largely Black youth drawn from the rural areas and townships. The industry is organised into taxi associations that are geographically defined. Manzi (2004) estimates that $60 \%$ of taxi industry employees do not earn fixed salaries, with monthly incomes ranging from R1000 to R1600. The minibus industry is characterised by a high level of migration, low level of education and stressful working conditions.

Assessment of HIV infection and AIDS in the transport industry has been done extensively amongst truck drivers, but not in the minibus industry. To our knowledge not much is known about the prevalence of HIV infection in this group, as well as their HIV prevention and promotion strategies. The issue of HIV infection and AIDS has not been explored in the minibus taxi industry in KwaZulu-Natal and, by extension, South Africa. Since the nature of work of minibus taxi drivers is different from that of truck drivers (Table 1), one can infer that interventions required to address HIV infection and AIDS in this occupational category would need to be tailormade to fit their situation.

\section{Aim of the study}

The study therefore intended to explore in depth minibus taxi drivers' sexual beliefs, practices and intricacies involved with regard to the spread of HIV infection, in order to develop appropriate strategies to address the problem in the minibus industry. Data from this study will help in designing effective strategies for sexual behaviour modification

TABLE 1: Differences between minibus taxi drivers and truck drivers.

\begin{tabular}{|c|c|}
\hline Minibus taxi industry & Truck drivers \\
\hline Informal workers & Formal workers \\
\hline Paid less, sometimes daily or weekly & $\begin{array}{l}\text { Slightly better paid and more } \\
\text { regularly than minibus taxi driver }\end{array}$ \\
\hline $\begin{array}{l}\text { Shorter-distance driving, except for a few doing } \\
\text { long distance }\end{array}$ & Long-distance travelling \\
\hline $\begin{array}{l}\text { Tend to attract younger girls, especially } \\
\text { schoolgirls, as girlfriends or one-night stands } \\
\text { but do not use ordinarily consult sex workers }\end{array}$ & Tend to consult sex workers \\
\hline $\begin{array}{l}\text { Usually have cash in hand on daily basis due } \\
\text { to fare collection }\end{array}$ & $\begin{array}{l}\text { Do not collect fares, thus less cash } \\
\text { in hand }\end{array}$ \\
\hline $\begin{array}{l}\text { Have free time during the day since they are } \\
\text { busy during peak hours, that is morning and } \\
\text { afternoon }\end{array}$ & On the road all the time \\
\hline
\end{tabular}

and prevention of HIV infection in this vulnerable occupational group.

\section{Research objectives}

The objectives of this study were to:

1. Assess the level of knowledge regarding HIV infection and AIDS in minibus taxi drivers.

2. Assess beliefs and practices regarding HIV infection and AIDS in minibus taxi drivers.

\section{Significance of the study}

The study was deemed important and relevant due to the increasing spread of HIV infection amongst young adults and adolescents, including school children, in South Africa and other parts of the world. Unpacking the beliefs and attitudes, sources of knowledge and information regarding HIV infection and AIDS amongst this fluid population of minibus taxi industry employees will enable targeted interventions to be designed. Data from this study will help in designing effective strategies for sexual behaviour modification and prevention of HIV infection and AIDS in this vulnerable occupational group of minibus taxi drivers.

\section{Literature review}

Traditionally, sex workers and truck drivers have been regarded as at the highest risk for infection with HIV. Recently minibus taxi drivers are emerging as another important vulnerable category (Porter et al. 2010; Skoch 2011). Some studies in Africa and India have associated long-distance truck drivers and minibus taxi drivers with increased risk of HIV infection (Rao et al. 1999; Ekanem et al. 2005; OlugbengaBello et al. 2007). HIV infection amongst minibus taxi drivers is a concern, because these people belong to an occupational group that exhibits some behaviours linked to the demands of their work, such as being away from their families for long times and in some cases being in an unhealthy environment and falling prey to unhealthy sexual practices.

Minibus taxi drivers appeal sexually to the schoolgirls due to the nature of their work, and therefore contribute to the spread of HIV infection (Porter et al. 2010). The minibus taxi drivers entice the schoolgirls by giving them money and allowing them to ride in their taxis. A research study in Nigeria has shown that intercity commercial taxi drivers were at increased risk of sexually transmitted infections due to frequent recourse to casual sex (Olugbenga-Bello et al. 2007). As a result, this group should be an important target for primary prevention of HIV infection. However, a variety of myths concerning HIV transmission remain strong. In a study conducted in the Caribbean, myths about HIV were found to be strong amongst a significant number of people and may possibly be a major factor impeding use of condoms (Figueroa 2008).

Concerns with condom use revolve around condom safety and breakage, condom ineffectiveness, disappearance of the condom into the vagina, decreased sexual pleasure, 
and condom use signifying infidelity or having asexually transmitted infection. Tackling such misperceptions remains a challenge for programmes and policies aimed at increasing condom use amongst sexually active men (Rauf et al. 2010; MacPhail \& Campbell 2001).

\section{Research methods and design Design}

An exploratory descriptive study was conducted between May and June 2009 amongst minibus taxi drivers in Durban, an urban centre in KwaZulu-Natal province, South Africa.

\section{Sampling and data collection}

A convenience sample of 175 minibus taxi drivers participated in this study. The sample was made up on a voluntary basis, and estimates of power were established with a sample size calculator based on the sampling frame of the number of minibus taxi drivers in the KwaZulu-Natal Taxi Alliance. A pre-tested questionnaire was administered directly by the researchers to collect data. We took advantage of midday, when there are fewer passengers, to distribute the questionnaires and explain the study to potential participants. Minibus taxi drivers who were willing to participate were then given informed consent information to sign. Information obtained from the respondents via the questionnaires was on knowledge of sexually transmitted diseases, HIV infection and AIDS, types of sexual partners and use of condoms.

A multi-itemed instrument was developed based on reviewed literature (Olugbenga-Bello et al. 2007; Figueroa 2008). The five-point Likert scale instrument was divided into three main sections which addressed the knowledge, attitudes or beliefs and practices of the minibus taxi drivers regarding HIV infection and AIDS. The instrument was pilot tested amongst 8-10 randomly selected participants before the onset of the main data collection, the aim of which was to assess stability and internal consistency. The Cronbach alpha coefficient of the multi-itemed instrument for the knowledge, attitudes or beliefs and practices (i.e. 76 items) was 0.89 . A testretest amongst the randomly selected participants yielded no significant differences in the participants' reporting of the items of the instrument, so no changes were made to the instrument. Content validity ensured that the items in the respective sections (i.e. knowledge, attitudes or beliefs and practices) related to each research objective.

\section{Ethical considerations}

Ethical clearance for the project was obtained from the University of KwaZulu-Natal Human and Social Sciences Ethics Committee (ethics number HSS/0433/08). Permission to undertake the study was obtained from the KwaZulu-Natal Taxi Alliance which controls the activities of minibus taxi drivers. The aims and objectives of the study were discussed with the association executives, who later conveyed them to their members. Attempts at randomly selecting participants from the lists of minibus taxi drivers were not acceptable, but we were allowed to approach minibus taxi drivers and obtain individual permission to participate in the study.

\section{Data analysis}

The quantitative data were collated and analysed using the Statistical Package for Social Sciences 13.0 (SPSS 13.0) data base. Descriptive statistics were used to describe the study sample in relation to both dependant and independent variables.

\section{Results}

\section{Demographic characteristics of participants}

The overwhelming majority of the participants (98.3\%; $n=172)$ were male and only $1.7 \%(n=3)$ were female. Ages of the respondents ranged from 18 to 59 years, with mean age of 31.4 years. However, the majority of the respondents $(75.4 \%$; $n=132$ ) were below 35 years of age. In terms of education, $52.6 \%(n=92)$ had a Grade 11-12 level of education, $25.7 \%$ $(n=45)$ Grade 8-10 level and $14.9 \%(n=26)$ below Grade 7; only $6.9 \%(n=12)$ had tertiary education. Most of the respondents $(62.9 \% ; n=110)$ were single, $21.1 \%(n=37)$ were cohabiting, $14.9 \%(n=26)$ were married and the rest were either widowed or divorced (Table 2).

\section{Education and information about HIV and AIDS}

The majority $(64.0 \% ; n=112)$ had not attended any information sessions on HIV infection and AIDS, and $82.3 \%(n=144)$ claimed not to have been provided with any information on HIV infection and AIDS in their workplace. Most participants $(77.1 \% ; n=135)$ claimed that they hadn't come across any points for condom distribution, although $76 \%(n=134)$ agreed that having sex without a condom

TABLE 2: Demographic variables of participants.

\begin{tabular}{lll}
\hline Variables & $\boldsymbol{N}$ & $\mathbf{\%}$ \\
\hline Gender & 172 & 93.3 \\
Male & 3 & 1.7 \\
Female & 175 & 100 \\
Total & & \\
Age & 35 & 20 \\
18-20 years & 96 & 54.9 \\
21-35 years & 44 & 25.1 \\
36-59 years & 175 & 100 \\
Total & & \\
Level of education & 26 & 14.9 \\
Below Grade 7 & 45 & 25.7 \\
Grade 8-10 & 92 & 52.6 \\
Grade 11-12 & 12 & 6.8 \\
College and/or university & 175 & 100 \\
Total & & \\
Marital status & 110 & 62.8 \\
Single & 37 & 21.1 \\
Cohabiting & 26 & 14.9 \\
Married & 1 & 0.6 \\
Divorced & 175 & 0.6 \\
Widowed & 100 \\
Total & & \\
\hline & & \\
\hline
\end{tabular}

$n$, Given as number of participants. 
will expose a person to HIV. More than half $(57.1 \%$; $n=100)$ agreed that sexually transmitted infections will increase the chances of contracting HIV, whilst $54.9 \%(n=96)$ stated they were aware that HIV transmission can happen from mother to child. In terms of a cure for HIV infection and AIDS, $54.3 \%(n=95)$ believed that there was no cure, whilst $22.3 \%$ $(n=39)$ believed that there was a cure and $24.0 \%(n=41) \mathrm{did}$ not respond (Table 3).

\section{Patriarchy, masculinity and decision-making}

On issues of patriarchy, masculinity and decision-making, $62.9 \%(n=110)$ of respondents agreed that the man decides on the type of sex for the woman, and $60.0 \%(n=105)$ believed men are always ready to have sex, whilst $16.0 \%$ $(n=28)$ were not sure. About half of the participants $(50.3 \%$; $n=88$ ) believed men needed more sex than women, whilst $18.9 \%(n=33)$ were unsure. Of the total participants, $42.9 \%(n=75)$ believed women who have condoms in their possession are 'loose' or promiscuous, whilst $17.1 \%$ $(n=30)$ were unsure; $56.0 \%(n=98)$ believed it was the women's responsibility to avoid getting pregnant, and $12.0 \%$ $(n=21)$ were unsure. In terms of decision-making, $60.0 \%$ $(n=105)$ believed a man should have the final word in making decisions about sex, whilst $10.9 \%(n=19)$ did not respond.

On the issue of violence against women on demanding sex (Table 4$), 48.0 \%(n=84)$ believed there are situations when women deserve to be beaten, whilst $16.0 \%(n=28)$ did not know or were unsure. More than half $(54.3 \% ; n=95)$ stated that if insulted when demanding sex, they will defend their reputation with force if necessary, whilst $14.3 \%(n=25)$ were unsure. Some of the participants $(32.0 \% ; n=56)$ believed women should tolerate violence and even forceful sexual intercourse at home to keep the family together, and $57.1 \%$ $(n=100)$ claimed that they feel disgusted when they see a man asking for a woman's opinion.

\section{Sexual behaviour and practices}

Considering sexual behaviour and practices (Table 5), 90.3\% $(n=158)$ stated that they were sexually active and $74.3 \%$ $(n=130)$ admitted having had more than one sexual partner at a time in the past year. More than half of the participants $(54.3 \% ; n=95)$ admitted to having sexual intercourse without using condoms; only $45.7 \%(n=80)$ use condoms, whilst $37.1 \%(n=65)$ admitted to using condoms only with some sexual partners whom they considered high risk. Sexual relations with sex workers in the past year was reported by $52 \%(n=91)$ of the minibus taxi drivers.

\section{Discussion}

The findings of this study are consistent with recent reports on taxi drivers from elsewhere. For instance, Orisatoki and Oguntibeju (2010 in their study of taxi drivers operating at a major airport in St Lucia in the West Indies reported high knowledge of HIV infection $(78.3 \%$; $n=138)$, but affirmed that misconceptions still exist amongst them. They also stated that less than half of the minibus taxi drivers used condom
TABLE 3: Education and Information about HIV-infection and AIDS.

\begin{tabular}{|c|c|c|c|c|c|c|}
\hline \multirow[t]{2}{*}{ Items } & \multicolumn{2}{|c|}{ Yes } & \multicolumn{2}{|c|}{ No } & \multicolumn{2}{|c|}{ Missing } \\
\hline & $n$ & $\%$ & $n$ & $\%$ & $n$ & $\%$ \\
\hline $\begin{array}{l}\text { Have you attended any programme } \\
\text { on HIV-infection and AIDS? }\end{array}$ & 63 & 36.0 & 112 & 64.0 & 0 & 0 \\
\hline $\begin{array}{l}\text { Have you received information } \\
\text { on HIV-infection and AIDS at the } \\
\text { workplace? }\end{array}$ & 31 & 17.7 & 144 & 82.3 & 0 & 0 \\
\hline $\begin{array}{l}\text { Have you come across any point } \\
\text { for condom distribution? }\end{array}$ & 40 & 22.9 & 135 & 77.1 & 0 & 0 \\
\hline $\begin{array}{l}\text { Having sex without condom will } \\
\text { expose a person to HIV }\end{array}$ & 133 & 76.0 & 42 & 24.0 & 0 & 0 \\
\hline $\begin{array}{l}\text { Having sexually transmitted } \\
\text { infections will increase the } \\
\text { chances of contracting HIV } \\
\text { infection }\end{array}$ & 100 & 57.1 & 75 & 42.9 & 0 & 0 \\
\hline $\begin{array}{l}\text { HIV transmission can happen } \\
\text { from mother to child }\end{array}$ & 96 & 54.9 & 79 & 45.1 & 0 & 0 \\
\hline There is no cure for AIDS & 65 & 54.3 & 39 & 22.3 & 41 & 3.4 \\
\hline
\end{tabular}

$n$, Given as number of participants.

TABLE 4: Issues of patriarchy, masculinity and violence against women.

\begin{tabular}{|c|c|c|c|c|c|c|}
\hline \multirow[t]{2}{*}{ Items } & \multicolumn{2}{|c|}{ Yes } & \multicolumn{2}{|c|}{ No } & \multicolumn{2}{|c|}{ Unsure } \\
\hline & $n$ & $\%$ & $n$ & $\%$ & $n$ & $\%$ \\
\hline $\begin{array}{l}\text { Men decide for women on how } \\
\text { to have sexual intercourse }\end{array}$ & 110 & 62.9 & 65 & 37.1 & 0 & 0 \\
\hline $\begin{array}{l}\text { Men are always ready to } \\
\text { have sexual intercourse }\end{array}$ & 105 & 60.0 & 42 & 24.0 & 28 & 16 \\
\hline $\begin{array}{l}\text { Men needed sex more } \\
\text { than women }\end{array}$ & 88 & 50.3 & 54 & 30.9 & 33 & 18.8 \\
\hline $\begin{array}{l}\text { Women who have condoms in } \\
\text { their possession are loose or } \\
\text { promiscuous }\end{array}$ & 75 & 42.9 & 70 & 40.0 & 30 & 17.1 \\
\hline $\begin{array}{l}\text { It is the women's responsibility } \\
\text { to avoid getting pregnant }\end{array}$ & 98 & 56.0 & 56 & 32.0 & 21 & 12.0 \\
\hline $\begin{array}{l}\text { Men should have a final say in } \\
\text { making decisions about sex }\end{array}$ & 105 & 60.0 & 51 & 29.1 & 19 & 10.9 \\
\hline $\begin{array}{l}\text { There are situations when } \\
\text { women deserve to be beaten } \\
\text { before sex }\end{array}$ & 84 & 48.0 & 53 & 30.3 & 28 & 21.7 \\
\hline $\begin{array}{l}\text { If insulted while demanding sex, } \\
\text { I will defend my reputation } \\
\text { with force if necessary }\end{array}$ & 95 & 54.3 & 55 & 31.4 & 25 & 14.3 \\
\hline $\begin{array}{l}\text { Women should tolerate violence, } \\
\text { even forceful sexual intercourse, } \\
\text { to keep the family together }\end{array}$ & 56 & 32.0 & 119 & 68.0 & 0 & 0 \\
\hline $\begin{array}{l}\text { I feel disgusted when I see a man } \\
\text { asking for a woman's opinion }\end{array}$ & 100 & 57.1 & 75 & 42.9 & 0 & 0 \\
\hline
\end{tabular}

$n$, Given as number of participants.

TABLE 5: Sexual behaviour and practices.

\begin{tabular}{|c|c|c|c|c|c|c|}
\hline \multirow[t]{2}{*}{ Items } & \multicolumn{2}{|c|}{ Yes } & \multicolumn{2}{|c|}{ No } & \multicolumn{2}{|c|}{ Unsure } \\
\hline & $n$ & $\%$ & $n$ & $\%$ & $n$ & $\%$ \\
\hline Are you sexually active? & 158 & 90.3 & 17 & 09.7 & 0 & 0 \\
\hline $\begin{array}{l}\text { Did you have more than one } \\
\text { sexual partner at a time in the } \\
\text { past year? }\end{array}$ & 130 & 74.3 & 45 & 25.7 & 0 & 0 \\
\hline $\begin{array}{l}\text { Do you have sexual intercourse } \\
\text { without using condom? }\end{array}$ & 95 & 54.3 & 80 & 47.7 & 0 & 0 \\
\hline $\begin{array}{l}\text { Do you use condoms only with } \\
\text { sexual partners considered risky? }\end{array}$ & 65 & 37.1 & 110 & 62.9 & 0 & 0 \\
\hline
\end{tabular}

$n$, Given as number of participants.

consistently and identified affordability and availability as constraints to condom use. Despite extensive efforts by the South African health system and non-governmental organisations in promoting safe sex, condom use amongst the minibus taxi drivers is relatively low, with many still engaging in unprotected sexual activities. Multiple sexual partners are relatively common amongst the minibus taxi drivers, thus increasing the likelihood of transmitting HIV and other sexually transmitted infections to their partners. Of the participants $74.3 \%(n=130)$ admitted having more 
than one sexual partner at a time in the past year. This makes this group an important target for primary prevention interventions and calls for prompt action.

Surprisingly, $76 \%$ agreed that having sex without a condom will expose a person to HIV, whilst $22 \%$ still hold the erroneous belief that there is a cure for HIV infection. The situation in South Africa is similar to that in other African countries. For example, although many programmes for prevention of HIV infection and other sexually transmitted diseases are being carried out in Nigeria, the intra-city commercial bus drivers and motor park attendants (a group similar to long- distance drivers), have been virtually overlooked in the dynamics of HIV infection and AIDS. Minibus taxi drivers' sexual networking with a variety of women within and outside the parks also seems to suggest that they play a major role in transmitting HIV infection in urban communities in Nigeria. Anecdotal evidence has suggested that intra-city commercial bus drivers are involved in behaviours that are inimical to their reproductive health and that of their sexual partner (Ekanem et al. 2005).

Men's sexual behaviour places women at great risk of acquiring HIV infection, and contributes to HIV infection in women who often have less power to determine when, how and even where sex takes place. These beliefs and practices automatically result in abuse of the female gender and predispose them to avoidable conditions. Sexual abuse, especially of very young girls, is rarely reported but is common amongst minibus taxi drivers, who often engage in sexual activities with school-going girls. Increasing sexual activities amongst very young girls is introducing another dimension to HIV infection control as well as reproductive health as a whole. Whilst the young women become victims of sexual abuse and child labour, the older ones, in the process of hawking, engage in non-conventional commercial sex work with minibus taxi drivers and their assistants. Most of these minibus taxi drivers also engage in sexual relations with sex workers, increasing the risk of HIV infection to young girls even further.

It was also observed that most minibus taxi drivers are young unmarried men who have received little education and little information about HIV. They are further vulnerable to infection because they travel throughout the city during their work, encounter many different people, receive money, and sometimes find themselves pursued by women who hope the drivers will spend money on them (Taravella 2005). There is a need for intervention programmes with a focus on minibus taxi drivers and similar high-risk groups.

\section{Limitations of the study}

The sample was small and the study findings can therefore not be generalised within the taxi industry. Due to the lack of prior research studies on the topic, the literature review was limited and the findings could not be compared to those of previous studies.
There was also limited access to the minibus taxi drivers as they were always in a hurry and ended up not finishing the questionnaires in full.

\section{Conclusion}

This study revealed that minibus taxi drivers in the Durban metropole are a high-risk group in the spread of HIV infection and AIDS. The sample was drawn from a sampling frame of all taxi drivers in Durban, although participation was on a voluntary basis. The minibus taxi drivers have not been given the necessary education and need attention in relation to control and prevention of the spread of HIV infection and AIDS. There is an urgent need for workplace HIV infection prevention programmes targeted at the minibus taxi drivers. Prevention activities should incorporate the distribution of condoms amongst this group, as well as creating mechanisms for accessing circumcision. Steps need to be taken to educate this occupational group in order to modify their sexual behaviours. The government and non-governmental organisations should also make condoms available free of charge at public places such as, (1) taxi ranks, (2) toilets, (3) hotels, airports, (4) gas stations and pharmacies or health centres.

\section{Competing interests}

The authors declare that they have no financial or personal relationship(s) which may have inappropriately influenced them in writing this article.

\section{Author contributions}

B.N. (University of KwaZulu-Natal and G.M. (Human Sciences Research Council) were project leaders on this study. J.N. (University of KwaZulu-Natal) was responsible for data analysis, whilst S.M. (University of KwaZulu-Natal), P.P. (Durban University of Technology) and T.N. (University of KwaZulu-Natal) were extensively involved in the data collection. The manuscript was written by B.N., G.M. and T.M. University of KwaZulu-Natal

\section{References}

Bankole, A., Ahmed, F.H., Neema, S., Ouedraogo, C. \& Konyani, S., 2007, 'Knowledge of correct condom use and consistency of use among adolescents in four countries in sub-Saharan Africa', African Journal of Reproductive Health 11, 198-220. http://dx.doi.org/10.2307/25549740, PMid:18458741, PMCid:2367135

Ekanem, E.E., Afolabi, B.M., Nuga, A.O. \& Adebajo, S.B., 2005, 'Sexual behaviour, HIV-related knowledge and condom use by intra-city commercial bus drivers and motor park attendants in Lagos, Nigeria', African Journal of Reproductive Health 9 , 78-87. http://dx.doi.org/10.2307/3583162, PMid:16104657

Evian, C., Fox, M., MacLeod, W., Slotow, S.J. \& Rosen, S., 2004, 'Prevalence of HIV in workforces in southern Africa, 2000-2001', South African Medical Journal 94, 125-130. PMid:15034992

Figueroa, J.P., 2008, 'The HIV Epidemic in the Caribbean: meeting the challenges of achieving Universal access to prevention, treatment and care', West Indies Medical Journal 57, 195-203.

Guiella, G. \& Madise, N.J., 2007, 'HIV/AIDS and sexual-risk behaviours among Adolescents, Factors influencing the use of condoms in Burkina Faso', African Journal of Reproductive Health 11, 182-196. http://dx.doi.org/10.2307/25549739, PMid:18458738, PMCid:2367130

MacPhail, C. \& Campbell, C., 2001, "I think condoms are good but, aai, I hate those things": Condom use among adolescents and young people in a Southern African township', Social Science \& Medicine 52(11), 1613-1627. PMid:11327136

Manzi, J.R., 2004, 'The Socio-economic and political impact of the formalization and recapitalization process of the taxi industry: a Case Study of the Durban Greater
North Taxi Region, Region 7', Master of Science of Geography and Environmental Studies, Faculty of Science and Engineering, University of KwaZulu-Natal. 
Olugbenga-Bello, A.I., Oboro, V.O., Parakoyi, D.B. \& Akande, T.M., 2007, Sexual risk behaviours of intercity commercial drivers in Ilorin, Kwara State, Nigeria, Research Journal of Medical Science 1, 284-288.

Orisatoki, R.O. \& Oguntibeju, O.O., 2010, 'HIV-related knowledge and condom use by taxi drivers in Southern St Lucia, West Indies', Scientific Research and Essays $5,304-308$.

Parker, W., Makhubele, B., Ntlabathi, P. \& Connolly, C., 2009, Concurrent sexua partnering amongst young adults in South Africa: Challenges for HIV prevention, Centre for AIDS Development, Research and Evaluation (CADRE), South Africa, viewed 27 March 2009, from http://www.jhuccp.org/legacy/countries/south_ africa/

Porter, G., Hampshire, K., Abane, A., Robson, E., Munthali, A., Mashiri, M. et al., 2010, 'Moving young lives: Mobility, immobility and inter-generational tensions in urban Africa', Geoforum 41(5), 796-804. http://dx.doi.org/10.1016/j. geoforum.2010.05.001

Rao, K.S., Pilli, R.D., Rao, A.S. \& Chalam, P.S., 1999, 'Sexual lifestyle of long distance lorry drivers in India: questionnaire survey', British Medical Journal 318, 162-163. http://dx.doi.org/10.1136/bmj.318.7177.162, PMid:9888910, PMCid:27695

Rauf, W., Hitchcock, S., Rauf, A. \& Becker, P.J., 2010, 'Knowledge of and misconceptions about the spread and prevention of HIV infection among older urban women attending the Tshwane District Hospital, South Africa', South African Family Practice 52(2), 142-148.
Shisana, O., Rehle, T., Simbayi, L.C., Zuma, K., Jooste, S., Pillay-van Wyk, V.et al., 2009, South African national HIV prevalence, incidence, behaviour and communication survey 2008: A turning tide among teenagers?, HSRC Press, Cape Town.

Skoch, I.R., 2011, 'Wanderlust: The taxi queens of South Africa. Swapping sex for free rides to school? Some South African girls think it's a good deal', Globalpost, 21 January 2011, viewed 22 January 2011, from

http://www.globalpost.com/dispatch/africa/101213/wanderlust-taxi-queens-southafrica-aids

Taravella, S., 2005, 'Driving HIV Away: helping taxi drivers protect themselves and others', Family Health International, May, 1-6.

UNAIDS, 2008, Report on the global AIDS epidemic, Geneva, viewed 01 February 2011 from

http://www.unaids.org/en/dataanalysis/epidemiology/2008reportontheglobalaidse pidemic/

UNAIDS, 2010, Country Progress Report on the Declaration of Commitment on HIV/ AIDS 2010 Report, Reporting Period: January 2008 - December 2009, Final Report 31 March 2010, UNAIDS, Geneva.

Vass, J., 2005, A Review of Labour Markets in South Africa, The Impact of HIV/AIDS on the Labour Market in South Africa. Employment and Economic Policy Research Programme, Human Sciences Research Council, viewed 04 January 2012, from http://www.hsrc.ac.za/research/output/outputDocuments/4206Vass Hivaids.pdf 